\title{
DENTISTS' KNOWLEDGE ABOUT MANAGEMENT OF TRAUMATIC DENTAL INJURIES IN A PART OF TURKEY: A CROSS-SECTIONAL STUDY
}

\begin{abstract}
Objectives: The aim of the present study was to evaluate the level of knowledge of general dental practitioners (GDPs) and dental specialists (DSs) about the management of Traumatic Dental Injuries (TDIs).
\end{abstract}

Materials and methods: A total of 199 participants from three cities in Turkey completed the online questionnaires. The first section of the questionnaire consisted of personal information about the dentists, while the second section consisted of multiple-choice questions regarding their knowledge of managing different types of TDIs in children. The data were statistically analyzed using the Chi-square test or Fisher's test and Mann-Whitney U test or Kruskal Wallis test. The level significance was taken as 0.05 in all tests.

Results: The questionnaires were completed by 145 GDPs and 54 DSs. In total, $29.1 \%$ of the participants (58) had less than 3 years of experience, $20.6 \%$ (41) had between 3 and 6 years of experience, $16.1 \%$ (32) had between 7 and 10 years of experience, $14.1 \%$ (28) had between 11 and 15 years of experience, $8 \%$ (16) had between 16 and 20 years of experience, and $12.1 \%$ (24) had more than 20 years of experience in clinical practice. Dentists with fewer years of experience ( $<10$ years) were more knowledgeable than those with more years of experience $(p=0.001)$. Moreover, DSs were more knowledgeable than GDPs $(\mathrm{p}=0.002)$.

Conclusions: Our findings revealed a moderate level of knowledge about TDI management among dental practitioners. These findings highlight the need to improve dentists' knowledge about TDI treatment protocols.

Keywords: Attitudes, dental trauma, dentists, emergency, knowledge.
iD $*$ Volkan Ciftci ${ }^{1}$

D Buse Ayse Serin ${ }^{1}$

ORCID IDs of the authors:

V.C. 0000-0001-7365-9365

B.A.S. $\quad 0000-0001-6779-8166$

${ }^{1}$ Department of Pediatric Dentistry, Faculty of Dentistry, Cukurova University, Adana, Turkey.

Received : : 12.11 .2020

Accepted $\quad: 12.01 .2021$

How to Cite: Ciftci V, Serin BA. Dentists' Knowledge about Management of Traumatic Dental Injuries in a part of Turkey: A Cross-Sectional Study. Cumhuriyet Dent J 2021;24:1:

*Corresponding Author:

Çukurova Üniversitesi, Diş Hekimliği Fakültesi, Pedodonti A.D, 01330 Sarıçam Adana, Turkey.

Phone: +90 3223387234 GSM: +905365822906 


\section{INTRODUCTION}

Traumatic dental injuries (TDIs) are recognized as a serious and significant public health problem. In particular, their frequency and associated economic burden could affect the patients' quality of life. ${ }^{1,2}$ Dental injuries could range from simple crown fractures to avulsion. A few important interventions after dental injuries (especially in patients with complicated crown fractures and avulsion) can significantly affect the prognosis. ${ }^{3}$ In patients with TDIs, the prognosis could vary depending on the period elapsed, type of trauma, degree of mobility or luxation of the tooth, fracture location, the state of root development and the age of the patient. ${ }^{4}$

Inadequate treatment planning following TDIs may result in psychological problems, pain and loss of function. In particular, accurate diagnosis and treatment planning are crucial in patients with avulsion injuries..$^{5-7}$ To minimize complications and enhance treatment outcomes, immediate and appropriate treatment management is often required. Therefore, for the management of TDIs, it is important that the level of knowledge of dental clinicians is sufficient and updated. ${ }^{8,9}$

The International Association of Dental Traumatology (IADT) is a professional organization whose mission is to promote optimal prevention, diagnosis, treatment, and follow-up services in the field of TDIs through interaction with dental and medical colleagues, the general public, and interested parties in education, sports, industry, public service, and governmental agencies across the globe. The IADT guidelines also offer recommendations for the diagnosis and treatment of specific TDIs and should assist dentists and patients in decision making and in providing the best care effectively and efficiently. ${ }^{10}$

Dental literature regarding TDIs reveals a low level of knowledge among dentists across the world regarding protocols for the emergency management of TDIs. ${ }^{11,12}$ Cinar et al. ${ }^{13}$ found limited knowledge among Turkish dentists about the management of TDIs regarding the splinting time for avulsed teeth and the treatment approach for complicated crown fractures. Similarly, a recent study revealed a low level of knowledge about TDIs among dentists in Turkey. ${ }^{14}$ Limited studies have assessed the knowledge level of Turkish dentists about TDIs based on their specialization status and experience. The aim of this crosssectional study was to evaluate the knowledge level of general dental practitioners (GDPs) and dental specialists (DSs) from three cities in Turkey about the emergency management of TDIs.

\section{MATERIAL AND METHODS \\ Study design and target population}

This cross-sectional study was conducted from April to October 2019. The participants were dentists working at university clinics and public and private practice clinics. An online questionnaire was sent to the dentists in Adana, Kahramanmaras, and Mersin provinces, Turkey, whose contact information was obtained through email or mobile phone. Ethical approval for the study was obtained from the Ethics committee for Non Invasive Researches, Faculty of Medicine, Çukurova University (ID: 86/35).

\section{Data collection}

The survey questions were modeled on a previously published study ${ }^{13}$. The questionnaire form was sent to a Turkish language expert in terms of linguistic validity and the form was finalized. A brief explanation of the purpose of the survey was provided on the first page of this questionnaire, and it was emphasized that participation was voluntary and that no individual dentist could be identified. The survey was divided into two sections. The first section consisted of six demographic questions, and the second section consisted of 12 multiplechoice questions (Table 1) regarding the participants' knowledge about emergency management of TDIs. A few participants submitted incompletely filled forms; therefore, they were excluded from the study. 
Table 1. Questions regarding the emergency management of TDIs 1.If an intruded primary maxillary anterior tooth has been
displaced toward the labial bone plate,

2.If an immature permanent maxillary tooth has been intruded, the tooth should be...

3.If a mature permanent maxillary tooth has been extruded, the tooth should be immediately repositioned and stabilised using a...

4.What type of splint should be used for extruded permanent incisors?

5.If a patient with an immature permanent maxillary tooth injury with pinpoint pulp exposure came to the clinic within 3 hours after the trauma, the treatment procedure would be...

6.If a patient with an immature permanent maxillary tooth injury with large pulp exposure came to the clinic more than 24 hours after the trauma, the treatment procedure would be...

7.If a patient with a mature permanent maxillary tooth injury with large pulp exposure came to the clinic more than 24 hours after trauma, the treatment procedure would be...

8. Which of the following storage media are suitable for the storage of an avulsed tooth?

9.If the patient comes to the clinic with in $60 \mathrm{~min}$ after trauma, before replantation, the immature avulsed tooth should be...

10.If the patient came to the clinic more than $60 \mathrm{~min}$ after trauma, for what period do you indicate the use of a splint for a mature avulsed tooth?

\begin{tabular}{ll} 
& $\begin{array}{l}\text { e. } 24 \text { hours } \\
\text { f. do not know }\end{array}$ \\
\hline 11.After replantation, do you prescribe antibiotic therapy? & $\begin{array}{l}\text { a. yes, tetracycline (>12 years old) } \\
\text { b. yes, penicillin } \\
\text { c. no }\end{array}$ \\
\hline 12.Should avulsed primary teeth be replanted? & $\begin{array}{l}\text { a. yes } \\
\text { b. no }\end{array}$ \\
\hline
\end{tabular}

a. the tooth is left for spontaneous repositioning

b. the tooth is immediately extracted

c. do not know

a. left alone for spontaneous repositioning

b. repositioned orthodontically

c. repositioned surgically

d. extracted immediately

e. do not know

a. rigid splint for 4 weeks

b. rigid splint for 2 weeks

c. semi-rigid splint for 2 weeks in conjunction with root canal treatment

d. semi-rigid splint for 2 weeks in conjunction with root canal treatment if pulp necrosis has occurred

a. semi-rigid with nylon wire

b. stainless steel wire

c. composite resin

d. other

a. do not treat but follow up

b. pulp capping

c. partial pulpotomy

d. cervical pulpotomy

e. pulpectomy

f. do not know

a. do not treat but follow up

b. pulp capping

c. partial pulpotomy

d. cervical pulpotomy

e. pulpectomy

f. do not know

a. do not treat but follow up

b. pulp capping

c. partial pulpotomy

d. cervical pulpotomy

e. pulpectomy

a. ice

b. tap water

c. paper tissue

d. fresh milk

e. patient's mouth

a. rinsed with tap water

b. cleaned with any type of solution

c. left unwashed

d. kept in doxcycline for $5 \mathrm{~min}$

e. scrubbed gently

f. kept in fluoride solution for $20 \mathrm{~min}$

g. do not know

a. no splint

b. 2 weeks

c. 4 weeks

d. 2 months

e. 24 hours

f. do not know

a. yes, tetracycline (>12 years old)

b. yes, penicillin

a. yes

Correct answers are written in bold. 
The first section of the survey was used to determine the socio-demographic and professional profiles of the participants (gender, age, and years of dental practice experience, practice type, and education level). The second section of the survey consisted of questions regarding the emergency management of TDIs. The questions were associated with the following topics concerning TDIs. ${ }^{13,15}$

- The emergency management of intrusive and extrusive luxation injuries (Q1-Q4)

- The emergency management of complicated crown fractures in immature and mature permanent teeth (Q5-Q7)

- The emergency management of avulsion injuries (Q8-Q12)

The accuracy of the answers was determined on the basis of evidence from the current dental trauma guidelines proposed by the IADT. ${ }^{16}$ The knowledge level of the participants was determined using a scoring system (0-12); one point was assigned for one correct answer. The categorization of knowledge levels according to the total scores received by participants was made as follows; $0-4$ scores were described as low, 4-8 scores were described as moderate and 8-12 scores were described as high levels of knowledge.

\section{Statistical analysis}

After the collection of data, the raw data were entered in statistical Package for the IBM SPSS

Table 2. Demographic characteristics of participants

\begin{tabular}{lll}
\hline & $\mathrm{n}$ & $\%$ \\
\hline Age & & \\
$<25$ & 34 & 17.1 \\
$25-35$ & 123 & 61.8 \\
$36-45$ & 27 & 13.6 \\
$46<$ & 15 & 7.5 \\
Gender & & \\
Male & 86 & 43.2 \\
Female & 113 & 56.8 \\
Years of experience & & \\
$1-3$ & 58 & 29.1 \\
$3-6$ & 41 & 20.6 \\
$7-10$ & 32 & 16.1 \\
$11-15$ & 28 & 14.1 \\
$16-20$ & 16 & 8.0 \\
$>20$ & 24 & 12.1 \\
\hline
\end{tabular}

Version 23 software (New York, USA). demographic information. Pearson's chi-squared test or Fisher's test was used to identify the correlation among gender, age, practice type, education level, and years of dental practice experience. Mann Whitney $\mathrm{U}$ test was used to compare continuous measurements between groups, and Kruskal Wallis test was used for more than two variable comparisons. The level significance was taken as 0.05 in all tests.

\section{RESULTS}

\section{Demographic distribution of participants}

From a total of 980, 199 (approximately 20.3\%) participants answered the survey. Of the total participants, 113 participants (56.8\%) were female, and $86(43.2 \%)$ were male. The majority of participants (61.8\%) were between 25 and 35 years old. $29.1 \%$ had 1 -3years experience, $20.6 \%$ had between 3-6 years, $16.1 \%$ had between $7-10$ years, $14.1 \%$ had $11-15$ years, $8 \%$ had between $16-20$ years and $12.1 \%$ had more than 20 years clinical experience. The distribution of participants according to the institutions they work in showed that $44.7 \%$ of participants work in public hospitals and $37.2 \%$ work in private practice. The percentage distribution of the participants in terms of their years of experience, age, and gender is summarized in Table 2. Descriptive statistics were used to summarize the 
Of the total 199 participants, 145 were GDPs and 54 were DSs. The majority of participants had no post-graduate degree $(72.9 \%)$. The specialty areas of DSs were Endodontics (5.5\%), Prosthodontics (5.5\%), Orthodontics (5\%), Pediatric dentistry (4\%),
Oral and maxillofacial surgery (3.5\%), Periodontics (2\%) and Restorative dentistry (1.5\%), respectively. The professional characteristics of all participants are shown in Table 3.

Table 3. Professional characteristics of the participants

\begin{tabular}{lll}
\hline & $\mathrm{n}$ & $\%$ \\
\hline Main practices & & \\
Public & 89 & 44.7 \\
Private & 74 & 37.2 \\
University & 30 & 15.1 \\
not specified & 6 & 3.0 \\
Specialization & & \\
No & 145 & 72.9 \\
Yes & 54 & 27.1 \\
Profession & & \\
General dental practice & 145 & 72.9 \\
Oral and maxillofacial surgery & 7 & 3.5 \\
Pediatric dentistry & 8 & 4.0 \\
Periodontics & 4 & 2.0 \\
Endodontics & 11 & 5.5 \\
Orthodontics & 10 & 5.0 \\
Prosthodontics & 11 & 5.5 \\
Restorative dentistry & 3 & 1.5 \\
\hline n=sample size, \%= percentage.
\end{tabular}

Knowledge of Emergency Management of Traumatic Dental Injures

Question 2 (treatment about intruded immature permanent teeth) and Question 7 (treatment procedure about a complicated crown fracture in mature teeth) had the highest rate of correct answers (69.8\% and $83.4 \%$, respectively). In contrast, Question 6 (treatment procedure about a complicated crown fracture in immature teeth) and Question 10 (splint time for a mature avulsed tooth) had the lowest rate of correct answers $(30.7 \%$ and $38.2 \%$, respectively). The percentage distribution of all participants' answers regarding the management of TDI is shown in Table 4.

Table 4. Percentage distribution of all participant's answers about emergency management of the TDI

\begin{tabular}{|c|c|c|}
\hline Questions & $\mathrm{n}$ & $\%$ \\
\hline \multicolumn{3}{|l|}{ Q.1 } \\
\hline The tooth is immediately extracted & 94 & 47.2 \\
\hline The tooth is left for spontaneous repositioning & 94 & 47.2 \\
\hline Do not know & 11 & 5.5 \\
\hline \multicolumn{3}{|l|}{ Q.2 } \\
\hline repositioned surgically & 17 & 8.5 \\
\hline extracted immediately & 3 & 1.5 \\
\hline left alone for spontaneous repositioning & 139 & 69.8 \\
\hline repositioned orthodontically & 34 & 17.1 \\
\hline Do not know & 6 & 3.0 \\
\hline \multicolumn{3}{|l|}{ Q.3 } \\
\hline rigid splint for 2 weeks & 6 & 3.0 \\
\hline semi-rigid splint for 2 weeks with root canal treatment if pulp necrosis has occurred & 118 & 59.3 \\
\hline semi-rigid splint for 2 weeks with root canal treatment & 62 & 31.2 \\
\hline rigid splint for 4 weeks & 13 & 6.5 \\
\hline \multicolumn{3}{|l|}{ Q.4 } \\
\hline composite resin & 42 & 21.1 \\
\hline semi-rigid with nylon wire & 111 & 55.8 \\
\hline
\end{tabular}


Ciftci V, et al.

\begin{tabular}{|c|c|c|}
\hline stainless steel wire & 37 & 18.6 \\
\hline other & 9 & 4.5 \\
\hline \multicolumn{3}{|l|}{ Q.5 } \\
\hline pulp capping & 115 & 57.8 \\
\hline pulpectomy & 12 & 6.0 \\
\hline cervical pulpotomy & 58 & 29.1 \\
\hline do not treat but follow up & 9 & 4.5 \\
\hline do not know & 5 & 2.5 \\
\hline \multicolumn{3}{|l|}{ Q.6 } \\
\hline partial pulpotomy & 61 & 30.7 \\
\hline pulp capping & 11 & 5.5 \\
\hline pulpectomy & 68 & 34.2 \\
\hline cervical pulpotomy & 48 & 24.1 \\
\hline do not treat but follow up & 4 & 2.0 \\
\hline do not know & 7 & 3.5 \\
\hline \multicolumn{3}{|l|}{ Q.7 } \\
\hline partial pulpotomy & 10 & 5.0 \\
\hline pulp capping & 1 & 0.5 \\
\hline pulpectomy & 166 & 83.4 \\
\hline cervical pulpotomy & 8 & 4.0 \\
\hline do not treat but follow up & 7 & 3.5 \\
\hline do not know & 7 & 3.5 \\
\hline \multicolumn{3}{|l|}{ Q.8 } \\
\hline ice & 3 & 1.5 \\
\hline patient's mouth & 72 & 36.2 \\
\hline paper tissue & 1 & 0.5 \\
\hline fresh milk & 123 & 61.8 \\
\hline \multicolumn{3}{|l|}{ Q.9 } \\
\hline kept in fluoride solution for $20 \mathrm{~min}$ & 25 & 12.6 \\
\hline kept in doxcycline for $5 \mathrm{~min}$ & 119 & 59.8 \\
\hline cleaned with any type of solution & 5 & 2.5 \\
\hline rinsed with tap water & 11 & 5.5 \\
\hline scrubbed gently & 5 & 2.5 \\
\hline left unwashed & 15 & 7.5 \\
\hline do not know & 19 & 9.5 \\
\hline \multicolumn{3}{|l|}{ Q.10 } \\
\hline 2 months & 10 & 5.0 \\
\hline 2 weeks & 76 & 38.2 \\
\hline 24 hours & 2 & 1.0 \\
\hline 4 weeks & 91 & 45.7 \\
\hline no splint & 5 & 2.5 \\
\hline do not know & 15 & 7.5 \\
\hline \multicolumn{3}{|l|}{ Q.11 } \\
\hline yes. tetracycline & 86 & 43.2 \\
\hline yes. tetracycline (>12 years old) & 86 & 43.2 \\
\hline no & 27 & 13.6 \\
\hline \multicolumn{3}{|l|}{ Q.12 } \\
\hline no & 180 & 90.5 \\
\hline yes & 19 & 9.5 \\
\hline
\end{tabular}

$\mathrm{Q}=$ question, $\mathrm{n}=$ sample size, $\%=$ percentage.

Comparing the numbers of correct answers to the questions among those who are GDP and DSs, the median value for correct answers for the GDPs is 7 (between 3-11 correct answers) and for the DSs is 9 (between 4-12 correct answers). It was found that there was a statistically significant difference in the mean correct answers given to the questions between those who were GDPs and DSs ( $\mathrm{p}=0.002)$.
When we compared the correct answers to the questions between DSs and GDPs, it was found that DSs had higher correct answers in Questions 4 and 8. This difference was also found to be statistically significant $(\mathrm{p}=0.036$ and $\mathrm{p}=0.014$, respectively). The distribution of the number of correct answers according to the specialist status is shown in Table 5 and Table 6. 
Table 5. The number of correct answers according to the specialist status

\begin{tabular}{lccc}
\hline & $\mathrm{n}$ & $\begin{array}{c}\text { Median } \\
(\text { Min-Max) }\end{array}$ & \\
\hline specialization & & $7(3-11)$ & $\mathrm{p}=0.002$ \\
no & 145 & $9(4-12)$ & \\
yes & 54 & & \\
\hline
\end{tabular}

Statistically significant at $\mathrm{p}<0.05, \mathrm{n}=$ sample size Min=minimum, Max=maximum.

Table 6. Distribution of the number of correct answers according to the specialist status

\begin{tabular}{|c|c|c|c|c|c|}
\hline & & & & & \\
\hline & $\mathrm{N}$ & $\%$ & $\mathrm{~N}$ & $\%$ & $\mathrm{p}$ \\
\hline Q 1 & 63 & 43.4 & 31 & 57.4 & 0.110 \\
\hline $\begin{array}{l}\text { Q } 2 \\
\text { correct } \\
\text { Q } 3\end{array}$ & 96 & 66.2 & 43 & 79.6 & 0.082 \\
\hline $\begin{array}{l}\text { correct } \\
\text { Q } 4\end{array}$ & 86 & 59.3 & 32 & 59.3 & 1.000 \\
\hline $\begin{array}{l}\text { correct } \\
\text { Q } 5\end{array}$ & 74 & 51.0 & 37 & 68.5 & 0.036 \\
\hline $\begin{array}{l}\text { correct } \\
\text { Q } 6\end{array}$ & 81 & 55.9 & 34 & 63.0 & 0.421 \\
\hline $\begin{array}{l}\text { correct } \\
\text { Q } 7\end{array}$ & 43 & 29.7 & 18 & 33.3 & 0.609 \\
\hline $\begin{array}{l}\text { correct } \\
\text { Q } 8\end{array}$ & 123 & 84.8 & 43 & 79.6 & 0.396 \\
\hline $\begin{array}{l}\text { correct } \\
\text { Q } 9\end{array}$ & 82 & 56.6 & 41 & 75.9 & 0.014 \\
\hline $\begin{array}{l}\text { correct } \\
\text { Q } 10\end{array}$ & 86 & 59.3 & 33 & 61.1 & 0.872 \\
\hline $\begin{array}{l}\text { correct } \\
\text { Q } 11\end{array}$ & 66 & 45.5 & 25 & 46.3 & 1.000 \\
\hline $\begin{array}{l}\text { correct } \\
\text { Q } 12\end{array}$ & 123 & 84.8 & 49 & 90.7 & 0.356 \\
\hline correct & 128 & 88.3 & 52 & 96.3 & 0.107 \\
\hline
\end{tabular}

Statistically significant at $\mathrm{p}<0.05, \mathrm{Q}=$ question, $\mathrm{n}=$ sample size, $\mathrm{GDP}=$ general dental practitioner, $\mathrm{DS}=$ dental specialist.

When we compared the numbers of correct answers to the questions according to the clinical experience of dentists, it was found that dentists with $<10$ years' experience had the highest rate of correct answers compared to other dentists (8 correct answers). The dentists who had 16-20 years of experience, had a moderate knowledge level (6 correct answers) when compared with their younger colleagues. This difference was found to be statistically different $(\mathrm{p}=0.001)$. The number of correct answers according to clinical experience is shown in Table 7.

Table 7. The number of correct answers according to the years of experience

\begin{tabular}{lccc}
\hline & $\mathrm{n}$ & $\begin{array}{c}\text { Median } \\
(\text { Min-Max) }\end{array}$ & \\
\hline clinical experience & & & \\
$<3$ & 58 & $8(4-11)$ & $\mathrm{p}=0.001$ \\
$3-6$ & 41 & $8(4-11)$ & \\
$7-10$ & 32 & $7(4-10)$ & \\
$11-15$ & 28 & $6(4-10)$ & \\
$16-20$ & 16 & $6(3-10)$ & \\
$20<$ & 24 & & \\
\hline
\end{tabular}

Statistically significant at $\mathrm{p}<0.05, \mathrm{n}=$ sample size, Min= minimum, Max=maximum.

\section{DISCUSSION}

The present study examined knowledge of TDIs, patient enrollment, and management regarding the IADT Guidelines for the management of TDIs among dentists in three cities of the Mediterranean region in Turkey. In this study, the mean knowledge score of GDPs was 7 and of DSs was 9 for 12 questions about emergency management of 
TDIs. It was observed that there was a significant difference between the knowledge score of DSs and GDPs $(\mathrm{p}=0.002)$. A recently published study reported that an average of 5.87 correct answer was given by Brazilian dentists about TDIs and that specialist dentists, such as endodontists and pediatric dentists, had the highest knowledge level of TDIs. ${ }^{17} \mathrm{Hu}$ et al..$^{18}$ reported that dental trauma knowledge level of endodontists was higher than the GDPs in Brazil. Zafar et al. ${ }^{19}$ found that the knowledge level about emergency management of tooth avulsion was significantly associated with the specialty of practice. Another study showed that specialists' knowledge level about emergency management of TDIs was higher than GDPs. ${ }^{20}$ Similar results were also reported in a study among German GDPs. ${ }^{21}$ Our results are comparable to the above studies with similar findings that knowledge about TDIs is in the moderate range. Less knowledge of TDIs may be explained by a lack of interest by clinicians regarding this topic because of the low incidence of experiencing trauma cases in their practice.

Dentists' professional education level, place of work and years of experience are crucial indicators of knowledge concerning the treatment of TDIs. In 2020, a study showed that the knowledge level of more experienced dentists was low in Turkey. ${ }^{22}$ Similarly, another study reported that more new graduates knew the answers to most of the questions. ${ }^{23}$ In this study, the dentists with fewer years of experience ( $<10$ years) were more knowledgeable ( 8 out of 12 questions) than dentists with more than 10 years of experience (6 out of 12 questions). This difference among dentists with different years of experience, based on the mean knowledge of TDIs, may be related to updated dental education and in part, by younger dentists having easier access to academic websites for research, such as IADT guidelines. These findings supported the findings of previously published reports evaluating the knowledge level in different countries. ${ }^{21,24,25}$

Different treatment alternatives have been suggested for the management of intruded permanent incisors, such as spontaneous reeruption, orthodontic extrusion, and surgical repositioning. The general consensus is that spontaneous re-eruption has been suggested for immature permanent teeth. ${ }^{26,27}$ In the present study, $47.2 \%$ of dentists said they would leave intrusively luxated primary teeth for spontaneous repositioning, and $69.8 \%$ of dentists said that they would prefer to leave intrusively luxated permanent teeth to spontaneously erupt.

In the present study, $59.3 \%$ of participants stated that they would immediately perform corrective repositioning and provide a splint in conjunction with root canal treatment if pulp necrosis had occurred. Cinar et al. ${ }^{13}$ reported that $50 \%$ of dentists responded that they would prefer a similar treatment approach. Similarly, another study reported that $47 \%$ of the dentists responded that they would base their decision more frequently on the result of a pulp test for extrusive and lateral injuries in their survey. ${ }^{28}$ Comparing the percentage of correct answers to the questionnaire among DSs and GDPs regarding intrusive injuries of primary and permanent teeth, there was no significant difference between the correct answers of GDPs and DSs regarding luxation traumatic injuries $(p \geq 0.005)$. A higher proportion of the participants showed inadequate knowledge of the treatment of intrusion and extrusion luxation injuries.

Comparing the percentage of correct answers to the questionnaire among DSs and GDPs regarding the type of splint material, there was a significant difference between the correct answers of GDPs and DSs ( $\mathrm{p}=0.036$ ). $68.5 \%$ of DSs and $51 \%$ of GDPs would provide a semi-rigid splint with nylon wire material. Cinar et al. ${ }^{13}$ reported that DSs were also more aware than GDPs regarding splinting time and material for mature extruded permanent incisors teeth.

The prognosis of complicated crown fracture appears to depend on the extent to which the pulp is exposed and the stage of root development at the time of injury. ${ }^{29}$ In mature and immature permanent teeth, if the amount of pulp exposure is small and treated within 24 hours, pulp capping has been suggested as the preferred treatment approach. ${ }^{30}$ A partial pulpotomy is indicated if the amount of pulp exposure is large, if the pulp has 
been open to bacterial contamination or if too much time has elapsed after the injury. ${ }^{28,31}$ In the present study, $57.8 \%$ of the participants preferred pulp capping a pin-point pulp exposure of an immature complicated crown fractured incisor as the correct answer. In contrast, $30.7 \%$ of participants preferred partial pulpotomy as the treatment for immature, complicated crown fractured incisors with large pulp exposure. Buldur and Kaplan reported that only $30.9 \%$ of their participants gave the correct answer. ${ }^{14}$. Alyasi et al. ${ }^{32}$ showed that only $33.1 \%$ of the participants answered this question correctly regarding the management of complicated crown fracture in immature teeth. According to these findings, the participants' knowledge of the emergency dental treatment of complicated crown fracture with pulp exposure was unsatisfactory.

Pulpectomy should be performed to preserve the tooth if the pulp becomes necrotic in cases of complicated crown fractured incisors with complete root formation. ${ }^{33}$ In the present study, the majority of participants $(83.4 \%)$ stated that they would immediately perform root canal treatment (pulpectomy) for this type of injury if there were closed apices with large pulp exposure more than 24 hours after trauma. Cinar et al. ${ }^{13}$ showed that $81.2 \%$ of participants would prefer root canal treatment, while Kostopoulu and Duggal ${ }^{15}$ found that $78 \%$ of GDPs would perform pulpotomy for a complicated crown fractured with a large exposure and open apex. Comparing the percentage of correct answers to the questions among DSs and GDPs regarding the type of complicated crown fracture with pulp exposure, there was no significant difference between the correct answers of GDPs and DSs ( $\mathrm{p} \geq 0.005)$.

The prognosis of avulsed teeth depends on whether appropriate emergency management procedures were performed. ${ }^{10}$ Immediate replantation is the most appropriate treatment for avulsed teeth. When immediate replantation is not possible, the use of a storage medium, extra-oral time, and the management of avulsed teeth are important for long term prognosis. Several studies have reported that fresh milk is superior to saliva as a storage medium. ${ }^{34,35}$ Zhao and Gong ${ }^{36}$ reported that most dentists preferred saliva or saline solution as a storage medium. In the present study, $61.8 \%$ of participants preferred milk as a storage medium for an avulsed tooth and $36.2 \%$ of the participants chose the patient's mouth (saliva) as the storage medium. Cinar et al. ${ }^{13}$ found that $63 \%$ of their participants preferred milk as storage, and Cohenca et al. ${ }^{12}$ reported that $53.6 \%$ of their participants identified milk as a storage medium for avulsed teeth. In this study, there was a significant difference between the responses of GDPs and DSs regarding the storage medium of an avulsed tooth $(\mathrm{p}=0.014)$. While $75.9 \%$ of DSs chose fresh milk, $56.6 \%$ of GDPs chose fresh milk as the storage medium.

Doxycycline has anti-bacterial, antiinflammatory effects and it could improve the prognosis and enhance the revascularization of avulsed teeth with an open apex. ${ }^{37}$ Shaul et al. ${ }^{38}$ stated that the use of root conditioning with doxycycline in avulsed teeth with closed apex resulted in complete healing at 16 months after the tooth replantation. Cinar et al. ${ }^{13}$ reported that $39.6 \%$ of dentists preferred doxycycline. In the present study, $59.8 \%$ of the participants stated they would place the avulsed teeth with an open apex in a doxycycline solution.

The technique of splinting should ensure physiological movement of an avulsed tooth after the replantation and during the healing period. IADT guidelines recommend flexible splinting (2 weeks) for avulsed teeth with closed apex if the extraoral drying time is longer than 60 minutes. ${ }^{16}$ In the present study, a low rate of the participants (38.2\%) chose the 2 weeks splinting period for mature avulsed teeth. Kostopoulu and Duggal ${ }^{15}$ reported that $10-30 \%$ of the dentists preferred a 2week splinting time. According to these findings, the participants' knowledge of the splinting time for an avulsed tooth was unsatisfactory.

The use of an antibiotic is effective in preventing a bacterial invasion of the pulp and inflammatory resorption after the replantation of an avulsed tooth. ${ }^{37}$ The IADT guideline also recommends the administration of systemic antibiotics, such as penicillin or doxycycline. ${ }^{10}$ In the present study, the majority of the participants (96.4\%) preferred antibiotics in cases of avulsion 
injuries. Similarly, a higher rate of all participants (90.5\%) presented the correct answer regarding the replantation of avulsed primary teeth. A previous study has also reported that $83 \%$ of the dentists were unwilling to replant primary teeth. ${ }^{12}$

\section{CONCLUSIONS}

Based on our findings, the level of Turkish general dental practitioners' knowledge about the management of TDIs was found to be moderate and also it could be concluded that postgraduate continuing education programs need to improve their knowledge about the management of TDIs. Furthermore, the awareness of dentists should be raised regarding the availability of the Turkish version of the IADT guideline, which was updated in 2020 (www.iadt-dentaltrauma.org), as well as the mobile phone application (Tooth SOS).

\section{ACKNOWLEDGEMENT}

The authors wish to thank all participants for their invaluable contribution to the present study. The authors would also like to thank Cagla Sariturk for statistical analysis of the present study and Roland Blankenstein, Furkan Kiraz, Abbas Merzhoev and Süleyman Dilek for kindest supports.

\section{CONFLICTS OF INTEREST STATEMENT}

The author declared no potential conflicts of interest with respect to the research, authorship, and/or publication of this article.

\section{FUNDING}

The author received no financial support for the research, authorship, and/or publication of this article.

\section{Türkiye'nin Bir Bölgesindeki Diş Hekimlerinin} Travmatik Dental Yaralanmaların Yönetimi Konusunda Bilgi Seviyesi: Kesitsel Bir Çalışma

\section{$\ddot{O} Z$}

Amaç: Bu çalışmanin amacı travmatik dental yaralanmaların (TDY) yönetimi konusunda genel diş hekimleri $(G D H)$ ve uzman diş hekimlerinin $(U D H)$ bilgi seviyelerini değerlendirmektir. Gereç ve Yöntemler: Çalışmaya Türkiye'deki ü̧ şehrinden elektronik anketleri dolduran toplam 199 katıllmcı dahil edildi. Anketin ilk bölümü diş hekimlerinin kişisel bilgilerini içerirken, ikinci bölüm diş hekimlerinin çocuklarda çeşitli dental travma tiplerinin yönetimindeki bilgi düzeyleri ile ilgili çoktan seçmeli sorulardan oluşturuldu. Elde edilen sonuçların istatistiksel analizi Ki-kare testi ya da Fisher's test ve Mann-Whitney U test ya da Kruskal Wallis testi kullanılarak yapıldı. Tüm testler için anlamlılı düzeyi 0.05 olarak alındl. Bulgular: Anketler 145 GDH ve 54 UDH tarafindan tamamlandl. Tüm katıllmclların \%29,1'inin (58) 3 ylldan daha az, \%20,6'sinin (41) 3-6 yll arasl, $\% 16,1$ 'inin (32) 7-10 yll arasl, \%14,1'inin (28) 11-15 yll arast, \%8'inin (16) 16-20 yll arast ve \%12,1'inin (24) ise 20 ylldan daha fazla klinik tecrübesi vardl. Daha fazla klinik tecrübeye sahip diş hekimlerine göre daha az klinik tecrübeye sahip (10 ylldan az) diş hekimlerinin bilgi düzeyinin daha fazla olduğu bulundu $(p=0,001)$. Ayrıca, UDH'nin bilgi düzeyi GDH'nin bilgi düzeyinden daha fazlayd $(p=0,002)$. Tartşsma: Bulgularımız TDY'ın yönetiminde diş hekimlerinin bilgi düzeyinin orta seviyede olduğunu ortaya çıkarmışstı. Bu sonuçlar TDY'lardaki tedavi protokolleri hakkında diş hekimlerinin bilgi seviyesinin gelişstirilmesi gerektiğini vurgulamaktadır. Anahtar Kelimeler: Davranıs, dental travma, acil, bilgi düzeyi.

\section{REFERENCES}

1. Westphalen VP, Martins WD, Deonizio MD, da Silva Neto UX, da Cunha CB, Fariniuk LF. Knowledge of general practitioners dentists about the emergency management of dental avulsion in Curitiba, Brazil. Dent Traumatol 2007;23: 6-8.

2. Unal M, Oznurhan F, Kapdan A, Aksoy S, Dürer A. Traumatic dental injuries in children. Experience of a hospital in the central Anatolia region of Turkey. Eur J Paediatr Dent 2014;15:17-22.

3. Traebert J, Lacerda JT, Foster Page LA, Thomson WM, Bortoluzzi MC. Impact of traumatic dental injuries on the quality of life of schoolchildren. Dent Traumatol 2012; 28:423-428.

4. Andreasen JO, Lauridsen E, Gerds TA, Ahrensburg SS. Dental Trauma Guide: A source of evidence-based treatment guidelines for dental trauma. Dent Traumatol 2012; 28:345-350.

5. Andrade RA, Evans PL, Almeida AL, Silva JD, Guedes AM. Guedes F.R., Ranalli D.N., Modesto A., Tinoco E.M. Prevalence of dental trauma in Pan American games athletes. Dental Traumatol 2010; 26:248-253.

6. Andreasen JO, Bakland LK, Matras RC, Andreasen 
FM. Traumatic intrusion of permanent teeth. Part 1. An epidemiological study of 216 intruded permanent teeth. Dent Traumatol 2006; 22:83-89.

7. Arhakis A, Athanasiadou E, Vlachou C. Social and psychological aspects of dental trauma, behavior management of young patients who have suffered dental trauma. Open Dent J 2017;11:41.

8. Pedrini D, Panzarini SR, Poi WR, Sundefeld ML, Tiveron AR. Dentists' level of knowledge of the treatment plans for periodontal ligament injuries after dentoalveolar trauma. Braz Oral Res 2011; 25:307-313.

9. De França RÍ, Traebert J, De Lacerda JT. Brazilian dentists' knowledge regarding immediate treatment of traumatic dental injuries. Dent Traumatol 2007; 23:287290.

10.Andersson L, Andreasen JO, Day P, Heithersay G, Trope M. International Association of Dental Traumatology guidelines for the management of traumatic dental injuries: 2. Avulsion of permanent teeth. Dent Traumatol 2012;28:88-96.

11.Cauwels RG, Martens LC, Verbeeck RM. Educational background of Flemish dental practitioners and their perceptions of their management of dental trauma. Dent Traumatol 2014;30:133-9.

12. Cohenca N, Forrest JL, Rotstein I. Knowledge of oral health professionals of treatment of avulsed teeth. Dent Traumatol 2006; 22:296-301.

13.Cınar C, Atabek D, Alaçam A. Knowledge of dentists in the management of traumatic dental injuries in Ankara, Turkey. Oral Health Prev Dent 2013; 11: 2330 .

14.Buldur B, Kapdan A. Factors associated with knowledge and attitude of management of traumatic dental injuries: A cross-sectional study among Turkish dentists. Pesqui Bras Odontopediatria Clín Integr 2018;18:3948.

15.Kostopoulou MN, Duggal M. A study into dentists' knowledge of the treatment of traumatic injuries to young permanent incisors. Int $\mathrm{J}$ Paediatr Dent 2005;15:10-19.

16.Levin L, Day PF, Hicks L, O'Connell A, Fouad $\mathrm{AF}$, Bourguignon $\mathrm{C}$, Abbott PV. International Association of Dental Traumatology guidelines for the management of traumatic dental injuries: General
Introduction. Dent Traumatol 2020; 36:309-313.

17.Hartmann RC, Rosseti BR, Pinheiro LS, Figueiredo JAP, Fedele GR, Gomes MS, Borba MG. Dentists' knowledge of dental trauma based on the International Association of Dental Traumatology guidelines: A survey in South Brazil. Dent Traumatol 2019; 35:27-32.

18.Hu LW, Prisco CRD, Bombana AC. Knowledge of Brazilian general dentists and endodontists about the emergency management of dento-alveolar trauma. Dent Traumatol 2006; 22:113-117.

19.Zafar K, Ghafoor R, Khan FR, Hameed MH. Awareness of dentists regarding immediate management of dental avulsion: Knowledge, attitude, and practice study. J Pak Med Assoc 2018; 68:595.

20.Alaslami RA, Elshamy FMM, Maamar EM, Ghazwani YH. Awareness about management of tooth avulsion among dentists in Jazan, Saudi Arabia. Open Access Maced J Med Sci 2018; 6:1712.

21.Krastl G, Filippi A, Weiger R. German general dentists' knowledge of dental trauma. Dent Traumatol 2009; 25:88-91.

22.Duruk G, Erel ZB. Assessment of Turkish dentists' knowledge about managing avulsed teeth. Dent Traumatol 2020;36:371-381.

23. Yavuz SB, Sadikoglu S, Sezer B, Toumba J, Kargul B. An Assessment of the Knowledge of Dentists on the Emergency Management of Avulsed Teeth. Acta Stomatol Croat 2020; 54:136.

24.Riyahi AM, Myman TA, Jarbou FA. Clinical-based Scenario Questionnaire About Dentists' Awareness of Tooth Avulsion Management in Riyadh City. J Adv Oral Res. 2020;11:52-6.

25.Zaleckiene V, Peciuliene V, Brukiene V, Jakaitiene A, Aleksejuniene J, Zaleckas L. Knowledge about traumatic dental injuries in the permanent dentition: A survey of Lithuanian dentists. Dent Traumatol 2018; 34:100-106.

26.Oulis C, Vadiakas G, Siskos G. Management of intrusive luxation injuries. Dent Traumatol 1996;12:113-119.

27. Medeiros RB, Mucha JN. Immediate vs late orthodontic extrusion of traumatically intruded teeth. Dent Traumatol 2009; 25: 380-385. 
28. Yeng T, Parashos P. An investigation into dentists' management methods of dental trauma to maxillary permanent incisors in Victoria, Australia. Dent Traumatol 2008.24: 443-448.

29.Robertson A, Andreasen FM, Andreasen JO, Noren JG. Long-term prognosis of crown-fractured permanent incisors. The effect of stage of root development and associated luxation injury. Int J Paediatr Dent 2000; 103: 191-199.

30.Flores MT, Andersson L, Andreasen JO, Bakland LK, Malm- gren B, Barnett F. Guidelines for the management of traumatic dental injuries. I. Fractures and luxations of permanent teeth. Dent Traumatol 2007; 23:66-71.

31.Olsburgh S, Jacoby T, Krejci I. Crown fractures in the permanent dentition: pulpal and restorative considerations. Dent Traumatol 2002; 18:103-115.

32. Alyasi M, Al Halabi M, Hussein I, Khamis AH, Kowash M. Dentists' knowledge of the guidelines of traumatic dental injuries in the United Arab Emirates. Eur J Paediatr Dent 2018; 19:271-6.

33.Güngör HC, Management of crown-related fractures in children: an update review. Dent Traumatol 2014; 30:88-99.

34.Souza BD, Luckemeyer DD, Felippe WT. Effect of temperature and storage media on human periodontal ligament fibroblast viability. Dent Traumatol 2010; 26:271-275.

35.Pearson RM, Liewehr FR, West LA, Patton WR, McPherson JC, Runner RR. Human periodontal ligament cell viability in milk and milk substitutes. J Endod 2003; 29:184-186.

36.Zhao Y, Gong Y. Knowledge of emergency management of avulsed teeth: a survey of dentists in Beijing, China. Dent Traumatol 2010;26:281-284.

37.Trope M. Clinical management of the avulsed tooth: present strategies and future directions. Dent Traumatol 2002;18:1-11.

38. Shaul L, Omri E, Zuckerman O, Imad AN. Root surface conditioning in closed apex avulsed teeth: a clinical concept and case report. Oral Surg Oral Med Oral Pathol Oral Radiol Endod 2009; 108:125-128. 